www.nature.com/ejhg

\title{
MtDNA and $Y$ chromosome polymorphisms in Hungary: inferences from the palaeolithic, neolithic and Uralic influences on the modern Hungarian gene pool
}

\author{
Ornella Semino ${ }^{1}$, Giuseppe Passarino ${ }^{1,2}$, Lluís Quintana-Murci ${ }^{1}$, Aiping Liu $^{1}$, Judit Béres ${ }^{3}$,

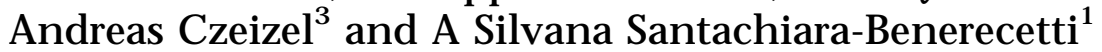

${ }^{1}$ Dipartimento di Genetica e Microbiologia 'A Buzzati Traverso', Università di Pavia; ${ }^{2}$ Dipartimento di Biologia Cellulare, Università della Calabria, Arcavacata di Rende, Italy; ${ }^{3}$ D epartment of Human Genetics and Teratology, National Institute of Hygiene, Budapest, Hungary

\begin{abstract}
Magyars imposed their language on Hungarians but seem not to have affected their genetic structure. To better investigate this point, we analysed some mtDNA and $Y$ chromosome polymorphisms in a sample of the Hungarian Palóc who, for historical reasons, could have retained genetic traces of Magyars more than other groups. In addition, we examined a mixed sample from Budapest. About 100 individuals were tested for the markers defining all the European and Asian mtDNA haplogroups and about $\mathbf{5 0}$ individuals for

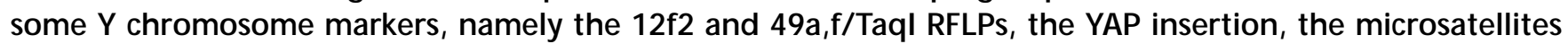
YCAIla, YCAllb, DYS19 and the Asian 50f2/C deletion. In the mtDNA analysis only two subjects belonged to the Asian $B$ and $M$ haplogroups. The $Y$ chromosome analyses showed that the Palóc differed from the Budapest sample by the absence of YAP ${ }^{+}$allele and by the DYS19 allele distribution; that the proto-European $49 \mathrm{a}, \mathrm{f} \mathrm{Ht} 15$ and the neolithic $12 \mathrm{f2}-8 \mathrm{~Kb}$ were rather uncommon in both groups; that there is a high prevalence of the 49a, f Ht 11 and the YCAll a5-b1; and that the Asian 50f2/C deletion is absent. These results suggest that the influence of Magyars on the Hungarian gene pool has been very low through both females and males and the Hungarian language could be an example of cultural dominance. Alternative explanations are discussed. An expansion centred on YAP'; 49a,f $\mathrm{Ht}^{-11}$ is revealed by the median network based on compound haplotypes. $49 \mathrm{a}, \mathrm{f} \mathrm{Ht} 11$ could represent either a paleolithic marker of eastern Europe which underwent expansion after the last glacial period, or a marker of the more recent spread of the Yamnaia culture from southern Ukraine. European Journal of Human Genetics (2000) 8, 339-346.
\end{abstract}

Keywords: Hungary; Palóc; mtDNA variations; Y chromosome polymorphisms

\section{Introduction}

Linguistic relationships among populations generally correlate with their genetic affinities. ${ }^{1,2}$ In Europe, the only populations of non-Indo-European language are the Basques and the Finno-Ugric speakers (Saami, Finns, Estonians and

Correspondence: Professor A Silvana Santachiara-Benerecetti,

Dipartimento di Genetica e Microbiologia 'A Buzzati Traverso',

Università di Pavia, Via Abbiategrasso, 207, 27100 Pavia, Italy. Tel:

+39 0382 505542/ 43; Fax: +390382 528496; E-mail:

santa@ipvgen.unipv.it

Received 23 April 1999; revised 5 January 2000; accepted 7 January

2000
Hungarians). The Finno-Ugric languages were brought from the Urals to eastern-Europe by migratory tribes. In Hungary, the Finno-Ugric language arrived with the Magyars who settled in the Carpathian Basin in 895 AD where other populations such as Slavs, Avars, and Bulgarians were present and subsequently assimilated. After the Magyar conquest, Hungary experienced other invasions, the most important of which was the Turkish, and also admixtures with neighbouring populations. ${ }^{3}$ It is a matter of debate as to what extent the Finno-Ugric invaders affected the genetic structure of the local pre-existing inhabitants. 
Analyses of classical markers showed that, as for the Finns, only about $10 \%$ of Hungarian genes could be of nonEuropean origin. ${ }^{4}$ Subsequently, mtDNA and $Y$ chromosome markers, which make it possible to identify separately male and female components in the genetic structure of a population, have been very helpful in revealing that the Uralic speakers, Finns and Saami, show almost exclusively mtDNA lineages of European ancestry ${ }^{5-8}$ but a considerable Y-specific lineage which can be traced back to Siberian and Central Asian peoples. ${ }^{9-11}$ An important Uralic male component has also been identified in Estonians. ${ }^{10}$ These findings are in agreement with the notion that $Y$ chromosome features parallel linguistic data more than do mtDNA and nuclear genes. ${ }^{12-14}$ By contrast, this Uralic Y-specific lineage was not observed in a sample of Csángó of Hungary ${ }^{15}$ and in mixed samples from Budapest. ${ }^{10-15}$

To increase our knowledge of the genetic structure of the Hungarian population, we analysed another ethnic group the Palóc, for some mtDNA and $Y$ chromosome polymorphisms, as well as a control sample from Budapest. Through these studies, not only could we investigate the Magyar contribution to the Hungarian genetic structure and verify if it was mainly male mediated, but we could also search for paleolithic and neolithic components in this eastern European population.

The mtDNA markers we used were the haplotypes defined by the six classic enzymes, ${ }^{16}$ and the restriction sites which identify all European and Asian specific haplogroups., ${ }^{77-19}$ As to $Y$ chromosome variations, the two Hungarian samples were analysed for the 50f2/C deletion, which has been considered to be a very valuable marker of the Uralic migrations; ${ }^{9}$ for the $49 a, f$ and $12 f 2 /$ Taq I RFLPs $^{20,21}$ which allowed some paleolithic and neolithic European male lineages to be highlighted. ${ }^{22}$ In addition, the $Y$ Alu polymorphism (YAP) which, as the $12 \mathrm{f} 2$ system, is a monophyletic bi-allelic marker, ${ }^{23}$ and the DYS19 and YCAlla and b microsatellites ${ }^{24,25}$ were examined. Compound haplotypes (c-Hts) were obtained by combining the single system 'alleles' for each individual, and were used to construct phylogenetic networks.

\section{Materials and methods The Palóc}

The Palóc live in a border region of the northern Carpathian basin ( $M$ atra, Figure1) neighbouring the Slavs in the higher mountains and speaking a specific Hungarian dial ect. Their origin is yet unclear. The Palóc land, first inhabited by western Slavs, was occupied by Magyars in the second half of the 10th century. Subsequent invasions from south-eastern and central Europe experienced by Hungary from the 14th century onward did not seem to have influenced the Palóc. They are believed therefore to be direct descendants of the Hungarians of the 10th-13th centuries. ${ }^{3}$

\section{The sample}

The sample consisted of 102 unrelated healthy subjects who gave their informed consent. Twenty-two were 'mixed Hungarians' from Budapest, and 80 were Palóc.

Blood specimens were collected in EDTA and buffy coats were separated and frozen within 24 hours. DNA was extracted according to standard methods.

\section{mtDNA analyses}

Six classical enzymes This analysis was performed according to Passarino et al. ${ }^{26}$

Haplogroup analyses With the exception of the Asian haplogroup $(\mathrm{Hg}) \mathrm{F}(-\mathrm{Hpal} / \mathrm{Hincll} 12406 \mathrm{site}), \mathrm{G}(+\mathrm{H}$ aell 4830 site) and T ( +Bam HI 13366 /-Ava II 13367 and -Mspl 15925 sites) which were detectable by the six classic enzyme analyses, the Caucasoid and the remaining Asian haplogroups were identified by PCR amplification of the relevant fragments ${ }^{26}$ and digestion with the appropriate enzymes. ${ }^{7,18,27}$

\section{Y chromosome analyses}

50f2/C deletion (DYS7C), and YAP insertion (DYS287) These polymorphisms were determined as described by Jobling et $\mathrm{al}^{9}$ and Hammer and Horai, ${ }^{23}$ respectively.

Taql $12 \mathrm{f2}$ and 49a,f polymorphisms (DYS11, DYS1) The conditions of these analyses are detailed in Passarino et al ${ }^{13}$

STRs analyses DYS19 and YCAII STRs were analysed according to Roewer et $\mathrm{al}^{24}$ and $\mathrm{M}$ athias et $\mathrm{al}^{25}{ }^{25}$ respectively.

\section{Phylogenetic analyses}

A median network, ${ }^{28}$ has been drawn with the Network 1.6 program. ${ }^{29}$ In this phylogeny the $\mathrm{YAP}^{+}$and $12 \mathrm{f} 2-8 \mathrm{~Kb}$ alleles were considered as separate lineages, and differences among microsatellites were considered according to the stepwise model, ${ }^{30}$ by weighting each single step as 1 ; similarly, each band acquisition and loss in the 49a,f system

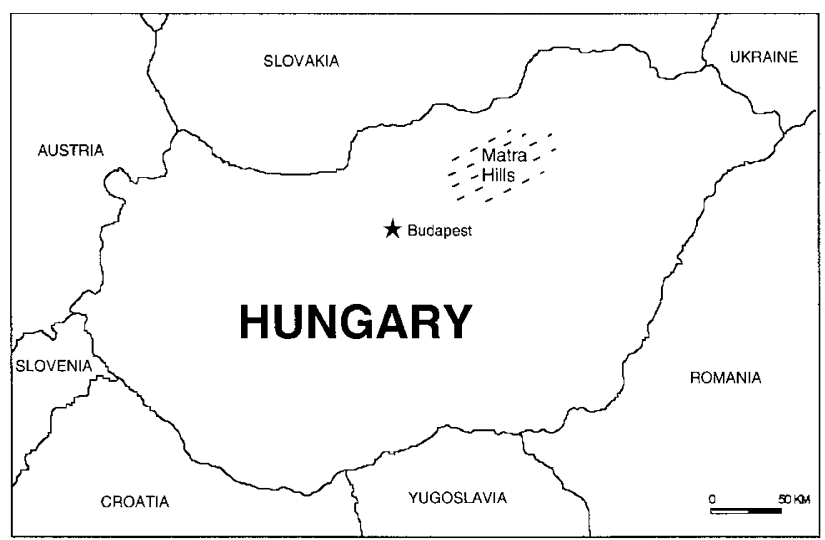

Figure 1 Map of Hungary showing the Matra region, where the Palóc sample was collected. 
was considered as a single step, by weighting the most variable $A$ band as $1^{31}$ and the other polymorphic fragments as 2.

\section{Results}

\section{MtDNA analyses}

The distribution of the mtDNA types defined by the 'six classic enzymes', together with that of the Caucasoid and the observed Asian specific haplogroups are reported in Tablel.

The 'six classic enzymes' analysis shows the profile of the Caucasoid populations, although with a lower frequency of types 6 and 18, and a particularly high frequency of type 1. Type 1 is the most represented type in Caucasoids, but it is very frequently also in Orientals. ${ }^{16,32}$ In this analysis, however, typical Oriental features, as those characterised by $\mathrm{Hpal}$ morph 1 (site loss at np 12406) or by Haell Morph 5 (site loss at $n p$ 4830), which define the Asian lineages $F$ and the $M$ subgroup $G$, respectively, ${ }^{33}$ were not observed. The frequency distribution of the continental specific haplogroups shows that $93.9 \%$ of the Hungarian mtDNAs were Caucasoid, $4.1 \%$ of unidentified origin, and only two subjects belonged to the Asian haplogroups $M$ (Budapest) and B (Palóc). As to the European mtDNA lineages, the two Hungarian groups significantly differ from each other for the $\mathrm{H}$ lineage $(50.6 \%$ in the Palóc vs $33.3 \%$ in the Budapest sample, $\mathrm{P}$ approximately 0.02). In both samples, this lineage, as in the other European populations, is the most frequent, followed by the $U$ (17.3\%). Haplogroups T, $\mathrm{K}$ and $\mathrm{V}$ occur at low frequencies $(2.0 \%, 2.0 \%$ and $1.0 \%$, respectively) and $X$ and I are absent. Haplogroup J, which is considered a neolithic arrival, ${ }^{19}$ has a frequency $(12.2 \%)$ in the range of the other European populations. Since all the four subjects of unidentified origin did not show any of the Asian haplogroup markers (also including the Alul site loss at np5176 which is an indicator of the Asian D del $_{10394}-$ Alul $_{10397}$ [--] sub-haplogroup $D^{19}$ ), these analyses indicated that at least $94 \%$ of the Hungarian mtDNAs have European characteristics. In agreement with other data ( $P$ Lahermo 1998, personal communication) these results suggest, therefore, that the female contribution of the Uralics to the Hungarian gene pool has been very low.

\section{Y chromosome analyses}

Data on $Y$ chromosome single polymorphisms are reported in Figure 2 and Tables2-4; the frequencies of the compound haplotypes (c-Hts) are given in Table5.

As shown in Figure2A, the 50f2/C deletion was not observed in the Hungarian sample, whereas it is quite common in Mongolians and especially in Siberians, Finns and Saami. ${ }^{9,11}$ Thus, in keeping with the finding of Zerjal et $\mathrm{al}^{10}$ and Lahermo et $\mathrm{al}^{15}{ }^{15}$ a genetic male contribution of Uralics into the Hungarian genetic structure has not been detected in this analysis.

Table 1 Associations between the mtDNA continent-specific haplogroups and classic enzymes types in Hungarians. Percent frequencies of haplogroups are compared with those of some relevant populations

\begin{tabular}{|c|c|c|c|c|c|c|c|c|c|c|c|c|c|c|c|}
\hline Haplogroups & pre-HV & $\mathrm{H}$ & V & U & W & $x$ & $\mathrm{~T}$ & J & K & 1 & M & B & Others ${ }^{b}$ & n.t. & Total \\
\hline \multicolumn{16}{|l|}{ Types $^{\mathrm{a}}$} \\
\hline $1.2(2.1 .1 .1 .1 .2)$ & 7 & 37 & 1 & 15 & & & & 10 & & & 1 & 1 & 4 & 4 & 80 \\
\hline 1.3 (2.1.1.1.1.3) & & 1 & & & & & & & & & & & & & 1 \\
\hline $6.2(2.1 .2 .1 .1 .2)$ & & & & & & & & & 2 & & & & & & 2 \\
\hline $15.2(2.1 .1 .1 .8 .2)$ & & 2 & & & & & & & & & & & & & 2 \\
\hline $18.2(2.3 .1 .4 .9 .2)$ & & & & & & & 1 & & & & & & & & 1 \\
\hline $21.2(2.1 .1 .1 .2 .2)$ & & & & & 3 & & & & & & & & & & 3 \\
\hline 21.9 (2.1.1.1.2.9) & & & & & 1 & & & & & & & & & & 1 \\
\hline 47.2 (2.1.1.1.3.2) & & & & & & & & 1 & & & & & & & 1 \\
\hline $57.2(2.3 .1 .4 .13 .2)$ & & & & & & & 1 & & & & & & & & 1 \\
\hline $59.2(2.1 .1 .1 .20 .2)$ & & & & 1 & & & & & & & & & & & 1 \\
\hline $72.2(2.1 .1 .1 .12 .2)$ & & 1 & & & & & & & & & & & & & 1 \\
\hline n.t. & 1 & 5 & & 1 & & & & 1 & & & & & & & 8 \\
\hline Total & 8 & 46 & 1 & 17 & 4 & - & 2 & 12 & 2 & - & 1 & 1 & 4 & 4 & 102 \\
\hline Hungarians $(n=98)$ & 8.2 & $46.9^{\mathrm{c}}$ & 1.0 & 17.3 & 4.1 & - & 2.0 & 12.2 & 2.0 & - & 1.0 & 1.0 & 4.1 & & \\
\hline Italians ${ }^{58}(n=99)$ & n.t. & 33.3 & 5.1 & 22.2 & 2.0 & 3.0 & 9.1 & 7.1 & 8.1 & 4.0 & - & - & 6.1 & & \\
\hline Swedes $^{7}(n=36)$ & n.t. & 40.5 & 5.4 & 16.2 & - & - & 21.6 & 2.7 & 13.5 & - & - & - & - & & \\
\hline Finns $^{7}(n=49)$ & n.t. & 40.8 & 4.1 & 16.3 & 4.1 & 4.1 & 6.1 & 14.3 & 4.1 & 2.0 & 2.0 & - & 2.0 & & \\
\hline Siberians $^{27}(n=153)$ & n.t. & - & n.t. & n.t. & - & - & - & - & - & - & 61.4 & - & 38.6 & & \\
\hline
\end{tabular}

n.t.=not tested; ${ }^{a} \mathrm{n}$ parentheses are the morphs defined by the enzymes Hpal, BamHI, Haell, Mspl, Avall, Hincll; ${ }^{\text {b}}$ These subjects were all Ddel $_{10394}$-Alul 10397 (- - ) and negative in the analyses for the markers of the Asian Ddel ${ }_{10394}$-Alul ${ }_{10397}(--)$ haplogroups. They were also negative when tested for the Alul site loss at np 5176 which is an indicator of the Asian haplogroup D, also including the sub-haplogroup D reverted from Ddel $_{10394}-$ Alul $_{10397}(++)$ to Ddel $_{10394}-$ Alul $_{10397}(--) ;{ }^{19}$ 'This value refers to the whole Hungarian sample. However, the Palóc frequency (50.6\%) significantly differs (P about 0.02 ) from that (33.3\%) of the Budapest sample. 
A

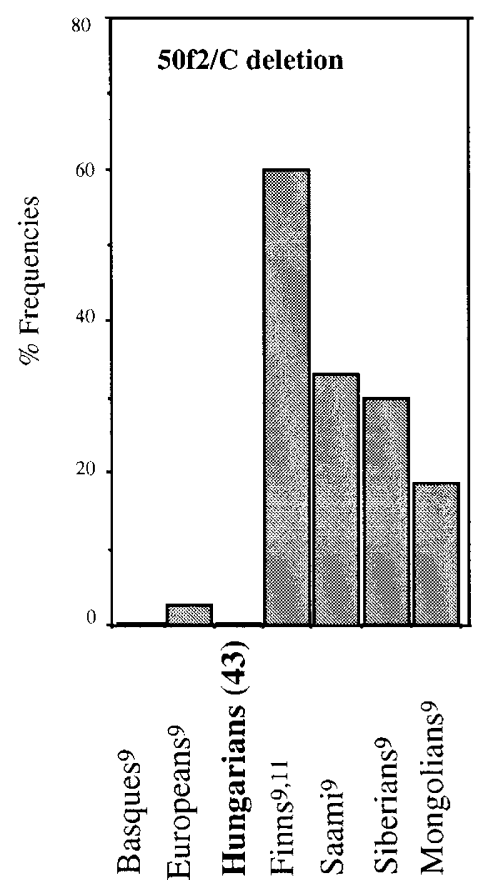

B
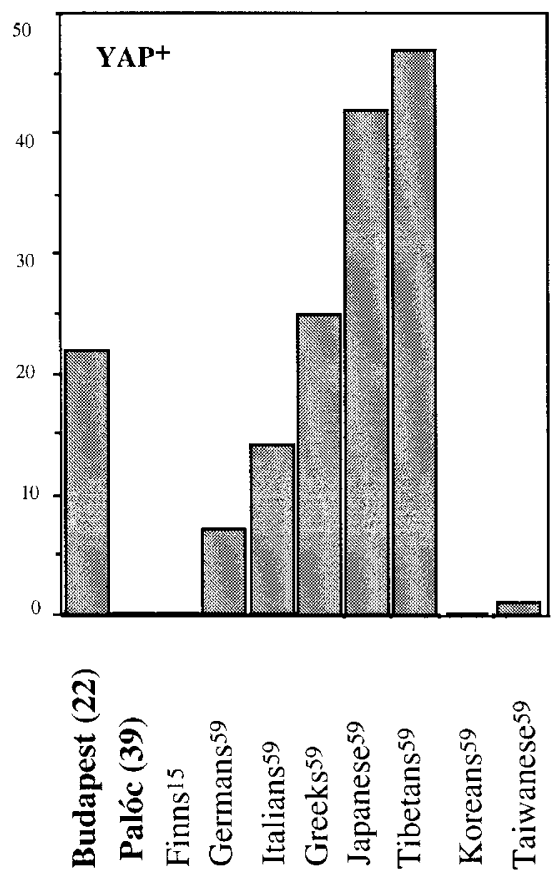

C

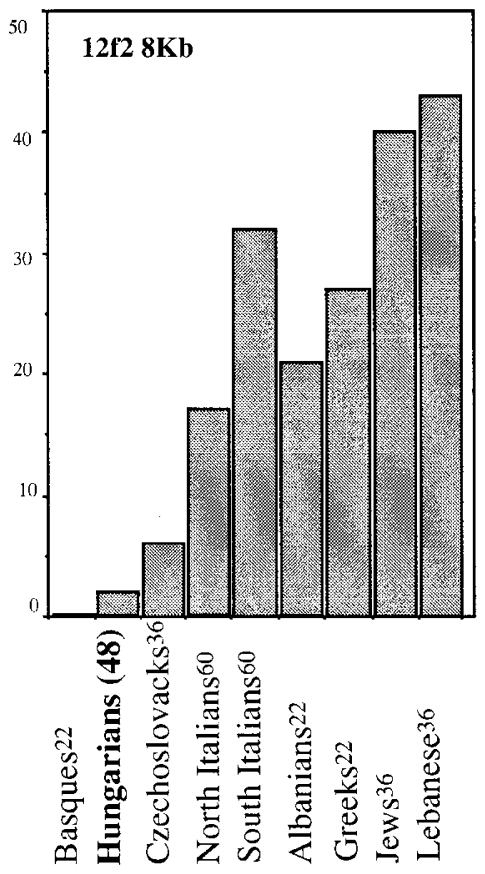

Figure 2 Distribution of $50 f 2 / C$ deletion (A), YAP ${ }^{+}$allele (B), and $12 f 2-8 \mathrm{~Kb}$ allele (C) in Hungarians compared with some relevant populations. Populations of the present study are in bold with sample size in parentheses.

As reported in Figure2B, all the $\mathrm{YAP}^{+}$chromosomes were observed in the mixed population of Budapest, where they account for $22.7 \%$ of the sample. This value is close to that (17.5\%) found in Budapest by Lahermo et al. ${ }^{15}$ Whereas in the Palóc the $\mathrm{YAP}^{+}$allele was not observed, it reaches a frequency of $37.5 \%$ in the Csángó. ${ }^{15}$

At the $12 \mathrm{f2}$ and $49 \mathrm{a}, \mathrm{f}$ RFLP analyses (Figure $2 \mathrm{C}$ and Table2, respectively), Hungarians display the neolithic $12 \mathrm{f} 2-8 \mathrm{~Kb}$ allele and the proto-European 49a,f haplotype15, both at low frequency. By contrast, they show an incidence of the 49a,f hapl otype 11 (42.5\%) which is by far the highest yet observed in a European population. ${ }^{34,35-38}$

Data relative to DYS19 are given in Table3. The Palóc do not display the DYS19 A allele and show one of the lowest frequencies so far encountered of the DYS19 C allele (6.7\%); the DYS19 B allele has a value (53.3\%) close to centralnorthern Europeans, ${ }^{14,39-41}$ whereas the DYS19 D allele reaches a frequency (26.7\%) similar to those of eastern European populations (31\% in Trieste and Bratislava) and of a group of Mongolians (30\%). ${ }^{39,41,42}$ The 'mixed Hungarians' of Budapest significantly differ from the Palóc sample ( $P=0.027$, Fisher exact test). They are more heterogeneous and show a high frequency (22.7\%) of the DYS19 A allele (as Romanians, $22 \%{ }^{39,41}$ ), lower frequencies of alleles DYS19 B and DYS19 D (31.8\% and $13.6 \%$, respectively) and a higher frequency of the DYS19 C allele (18.2\%). Both Hungarian samples show a relative high incidence of the DYS19 E allele (13-14\%).

In the YCAll analysis the two Hungarian groups were very similar and were pooled (Table4). The most important feature is the very high incidence of the YCAII a5-b1 haplotype (69.8\%). This frequency is one of the highest observed in Europe, ${ }^{14,25,39,41,43,44}$ and is close to the value (78\%) displayed by the Basques. ${ }^{45,46}$.

Table 5 shows the $22 \mathrm{c}-\mathrm{Hts}$ observed in the $46 \mathrm{Hungarians}$ typed for all the systems here analysed. Fourteen c-Hts were single observations. The two stable markers (YAP and 12f2) define three main $Y$ chromosome lineages: the $\mathrm{YAP}^{-} /$ $12 \mathrm{f} 2-10 \mathrm{~Kb}$, the $\mathrm{YAP}^{+} / 12 \mathrm{f} 2-10 \mathrm{~Kb}$, and the $\mathrm{YAP}^{-} / 12 \mathrm{f} 2-8 \mathrm{~Kb}$, separately shown in the full median network (Figure3). The first is the most important lineage where the most represented haplotypes carry the 49a,f Ht11, YCAII a5-b1 and DYS19 B combination. The other two lineages account only for $10.9 \%$ (c-Hts $1-3$ ) and $2.2 \%$ (c-Ht22) of the sample, respectively, and do not show the preferential associations found in the first lineage. The $\mathrm{YAP}^{+} / 12 \mathrm{f2}-10 \mathrm{~Kb}$ lineage shows preferential associations with 49a,f Ht 5 and DYS19 A allele, which is the most common north African combination and is also frequent in Greeks and Turks (AS SantachiaraBenerecetti, personal communication); the $\mathrm{YAP}^{-} / 12 \mathrm{f} 2-8 \mathrm{~Kb}$ lineage, here represented by only one c-haplotype, displays the association with $49 \mathrm{a}, \mathrm{f} \mathrm{Ht} 7$ and DYS19 B allele, which is a 
Table 2 Distribution of Taql/49a,f haplotypes in Hungarians and in two comparison populations

\begin{tabular}{|c|c|c|c|c|}
\hline Haplotypes $^{a}$ & $\begin{array}{l}\text { Polymorphic } \\
\text { fragments }^{b} \\
\text { A C D F I }\end{array}$ & $\begin{array}{l}\text { Hungarians } \\
n=47\end{array}$ & $\begin{array}{l}\text { Czechoslovaks } 36 \\
n=105\end{array}$ & $\begin{array}{l}\text { Italians }^{34} \\
n=125\end{array}$ \\
\hline 2 & 00111 & 2.1 & & 4.0 \\
\hline 5 & 20011 & 12.8 & 2.9 & 8.0 \\
\hline 7 & 20110 & 2.1 & & 9.6 \\
\hline 8 & 20111 & & 1.9 & 5.6 \\
\hline 10 & 30010 & 8.5 & 2.9 & 1.6 \\
\hline 11 & 30011 & 42.5 & 21.0 & 6.4 \\
\hline 12 & 30110 & 2.1 & 9.5 & 4.8 \\
\hline 13 & 30111 & 2.1 & 1.9 & 1.6 \\
\hline 15 & 31211 & 6.4 & 11.4 & 28.0 \\
\hline 24 & 21111 & & 4.8 & 5.6 \\
\hline 29 & $2 / 31211$ & & 3.8 & 7.2 \\
\hline 31 & $3 / 41211$ & & 1.0 & 1.6 \\
\hline 35 & 31011 & 6.4 & 8.6 & 5.6 \\
\hline 36 & 31210 & 2.1 & & 0.8 \\
\hline 37 & 31201 & & & 1.6 \\
\hline 39 & $30010-\mathrm{BHPR}$ & 4.2 & 1.0 & 0.8 \\
\hline 51 & $2 / 30011$ & 2.1 & 2.9 & \\
\hline 64 & $3 / 50011$ & 2.1 & 8.6 & \\
\hline 84 & 50011 & 6.4 & 4.8 & \\
\hline 85 & 00101 & & 2.9 & \\
\hline Others ${ }^{c}$ & & & 10.5 & 7.2 \\
\hline
\end{tabular}

aWith the exception of the first nine haplotypes all the others have been renamed according to the revised nomenclature of Poloni et al; ${ }^{12}$ ${ }^{b} 1$ and 0 denote presence and absence respectively of the band, except for the $A$ and the $D$ fragments, for which the numbers indicate which band of the allelic set is present; solidus indicates the presence of two allelic bands in the same haplotype, in which case a locus duplication was assumed ${ }^{34}$; Includes haplotypes found only in one subject of a single comparison group.
Table 3 Percent frequencies of the DYS19 alleles in the two Hungarian samples

\begin{tabular}{llll}
\hline Alleles & & $\begin{array}{l}\text { Palóc } \\
n=30\end{array}$ & $\begin{array}{l}\text { Budapest } \\
n=22\end{array}$ \\
\hline bp & & - & 22.7 \\
186 & A & 53.3 & 31.8 \\
190 & B & 6.7 & 18.2 \\
194 & C & 26.7 & 13.6 \\
198 & D & 13.3 & 13.6 \\
202 & E & & \\
\hline
\end{tabular}

Table 4 Percent frequencies of the YCAll haplotypes in Hungary

\begin{tabular}{llc}
\hline $\begin{array}{l}\text { YCAll } \\
\text { a b }\end{array}$ & Haplotypes & $\begin{array}{l}\text { Frequency } \\
n=53\end{array}$ \\
\hline $6 / 5$ & No. of repeats & 1.9 \\
$5 / 1$ & $24 / 23$ & 69.8 \\
$4 / 1$ & $23 / 19$ & 1.9 \\
$3 / 3$ & $22 / 19$ & 7.5 \\
$3 / 2$ & $21 / 21$ & 3.8 \\
$3 / 1$ & $21 / 20$ & 9.4 \\
$2 / 2$ & $21 / 19$ & 1.9 \\
$1 / 1$ & $20 / 20$ & 3.8 \\
\hline
\end{tabular}

Table 5 Y chromosome compound (c-Hts) haplotypes obtained by combining the different alleles observed, in each individual, for 50f2/C, YAP, 12f2, 49a,f, YCAll, DYS19 polymorphisms and their frequencies in percent

\begin{tabular}{|c|c|c|c|c|c|c|c|c|}
\hline \multirow[b]{2}{*}{$\mathrm{c}-\mathrm{Ht}$} & \multirow{2}{*}{$50 f 2 / C$} & \multirow{2}{*}{ YAP } & \multirow{2}{*}{$12 f 2$} & \multicolumn{2}{|c|}{$49 a, f$} & \multirow{2}{*}{$\begin{array}{l}\text { YCAll } \\
\mathrm{Ht} \\
\mathrm{a} \mathrm{b}\end{array}$} & \multirow{2}{*}{ DYS19 } & \multirow[b]{2}{*}{$n=46$} \\
\hline & & & & $\mathrm{Ht}$ & $\begin{array}{l}\text { fragments } \\
A C D F I\end{array}$ & & & \\
\hline 1 & - & + & 10 & 5 & 20011 & $3 / 1$ & A & 6.5 \\
\hline 2 & - & + & 10 & 5 & 20011 & $1 / 1$ & A & 2.2 \\
\hline 3 & - & + & 10 & 11 & 30011 & $3 / 3$ & A & 2.2 \\
\hline 4 & - & - & 10 & 2 & 00111 & $2 / 2$ & D & 2.2 \\
\hline 5 & - & - & 10 & 5 & 20011 & $5 / 1$ & $\mathrm{E}$ & 2.2 \\
\hline 6 & - & - & 10 & 5 & 20011 & $5 / 1$ & B & 2.2 \\
\hline 7 & - & - & 10 & 10 & 30010 & $3 / 3$ & $\mathrm{D}$ & 2.2 \\
\hline 8 & - & - & 10 & 10 & 30010 & $3 / 2$ & $\mathrm{D}$ & 4.4 \\
\hline 9 & - & - & 10 & 10 & 30010 & $3 / 2$ & C & 2.2 \\
\hline 10 & - & - & 10 & 11 & 30011 & $5 / 1$ & D & 10.9 \\
\hline 11 & - & - & 10 & 11 & $\begin{array}{lllll}3 & 0 & 0 & 1 & 1\end{array}$ & $5 / 1$ & $\mathrm{C}$ & 6.5 \\
\hline 12 & - & - & 10 & 11 & 30011 & $5 / 1$ & B & 23.9 \\
\hline 13 & - & - & 10 & 12 & 30110 & $3 / 1$ & B & 2.2 \\
\hline 14 & - & - & 10 & 13 & 30111 & $6 / 5$ & $\mathrm{D}$ & 2.2 \\
\hline 15 & - & - & 10 & 15 & 31211 & $5 / 1$ & $\mathrm{C}$ & 2.2 \\
\hline 16 & - & - & 10 & 15 & 31211 & $5 / 1$ & B & 4.4 \\
\hline 17 & - & - & 10 & 35 & 31011 & $5 / 1$ & $\mathrm{~B}$ & 6.5 \\
\hline 18 & - & - & 10 & 36 & 31210 & $5 / 1$ & $\mathrm{~B}$ & 2.2 \\
\hline 19 & - & - & 10 & 39 & 30010 -BHPR & $5 / 1$ & $\mathrm{C}$ & 2.2 \\
\hline 20 & - & - & 10 & 64 & $3 / 50011$ & $1 / 1$ & C & 2.2 \\
\hline 21 & - & - & 10 & 84 & 50011 & $5 / 1$ & $\mathrm{E}$ & 6.5 \\
\hline 22 & - & - & 8 & 7 & 20110 & $4 / 1$ & $\mathrm{~B}$ & 2.2 \\
\hline
\end{tabular}




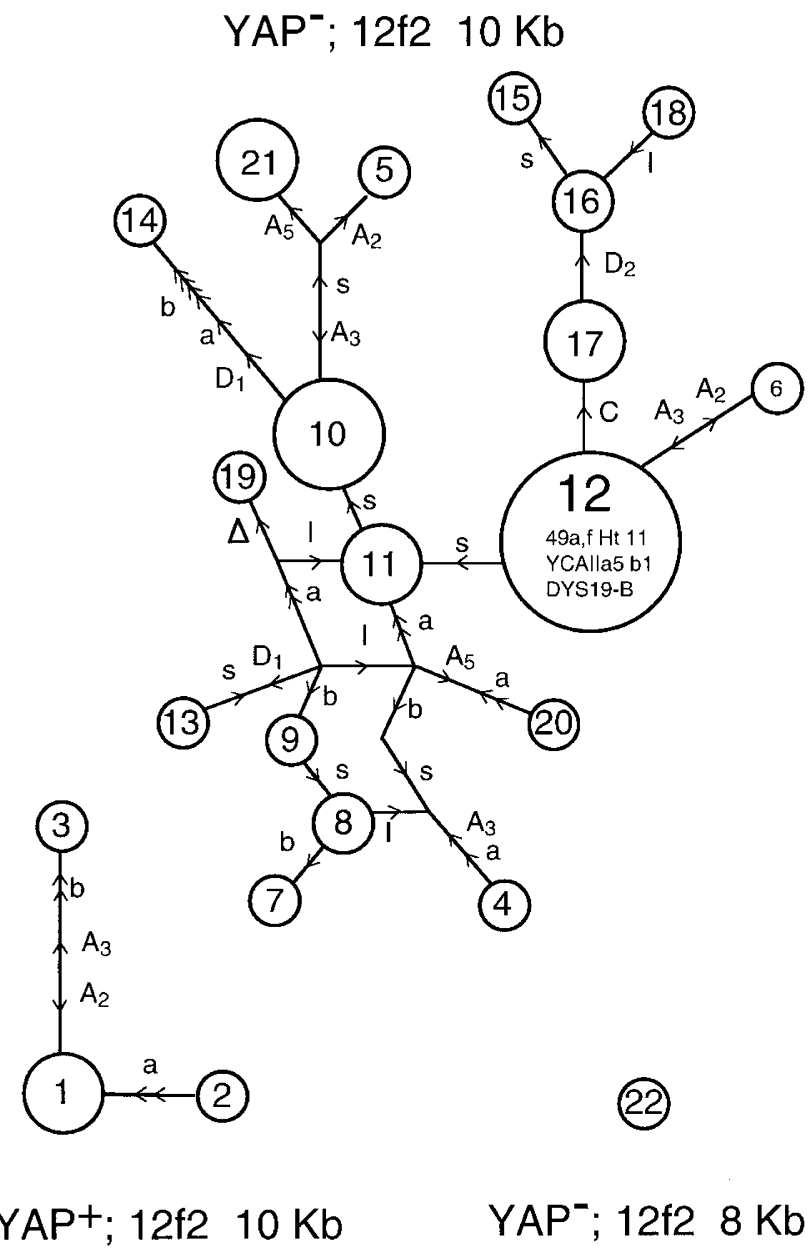

Figure 3 The full median network of the $Y$ chromosome compound haplotypes (c-Hts) found in Hungary. Numbers in circles indicate the corresponding c-Ht (see Table5) and the circle size is proportional to its frequency; arrows on the branches point to a repeat/fragment gain; capital letters represent fragment changes at 49a,f loci; small letters ( $a, b$, and s) represent changes at YCAlla, YCAllb and DYS19 loci, respectively; $\Delta$ represents the $49 a, f$ BHPR fragment deletion. ${ }^{34}$

combination very common in the Middle East (AS Santachiara-Benerecetti 1995, personal communication).

\section{Discussion}

\section{Uralic genetic component in Hungary}

Hungary is one of the few areas in Europe where a non-IndoEuropean language is spoken. This is due to the Magyar invasion, which at the end of the 9th century AD brought to the present Hungarian territory thousands of people (estimates vary from 50000 to 500000$)^{4}$ who spoke a Uralic language (the Magyar). The extent of genetic influence of the invaders on the Hungarian gene pool, which is still a puzzling problem, has been addressed by studying some mtDNA and $Y$ chromosome polymorphisms. These sets of markers have proved to be very valuable in estimating the extent of the Uralic gene flow into the gene pool of Saami, Finns and Estonians, $6,9,10,11$ who, like the Hungarians, speak a language of the Uralic family.

We have examined a Hungarian ethnic group, the Palóc, who are considered the direct descendants of the Hungarians of the Middle Ages and a control sample from the mixed population of Budapest.

The two groups are differentiated mainly by the frequencies of the mtDNA haplogroup $\mathrm{H}$, and the $\mathrm{Y}$ chromosome DYS19 B and YAP $^{+}$alleles which, in the European frame, are closer to central-northern and north-eastern Europeans in the Palóc, and to south-eastern Europeans in the Hungarians of Budapest. Both samples, however, virtually do not display Uralic characteristics. As to the mtDNA, the Asian lineages $B$ and $M$ were found only in one subject each; they, however, do not necessarily indicate evidence of Uralic entrance. Indeed, the $9 \mathrm{bp}$ deletion characterising the $B$ $\mathrm{Hg}$ is a recurrent mutation. ${ }^{17,47,48}$ As to the $\mathrm{M} \mathrm{Hg}$ (in the mixed sample from Budapest) it has to be taken into account that in Hungary there are groups of Gypsies with high frequencies of Hg M (A Pandya 1998, personal communication). On the male side, Hungarian $Y$ chromosomes lack the $50 f 2 / C$ deletion that is very common among Samoyedic and Altaic Siberians (Figure2A). Thus, unlike Finns, Estonians and Saami, where a strong Uralic male-mediated genetic influence was highlighted, Hungarians seem to have undergone a mainly Uralic cultural dominance imposed by a small number of invaders. Alternatively, a large number of Magyar speakers invaded Hungarian territory but only a few of them, from a genetic point of view, were truly Magyar. Actually, it has to be borne in mind that Magyars, after leaving the Finno-Ugric homeland about 3000 years ago, had 2000 years of nomadic life, with close contacts with other populations, especially Bulgarians and Kazars, mainly between the 4th and 9th centuries $\mathrm{AD}^{3}{ }^{3}$ This second hypothesis would be consistent with the historical view that the number of newcomers (whatever it was) was not very different from the number of previous inhabitants of Hungary. ${ }^{4}$

Nevertheless, it cannot be excluded that, at variance with the Fenno speakers who migrated toward northern Europe, Magyars did not harbour the 50f2/C del etion right from their origins. Were this the case, the $50 f 2 / C$ deletion would not be the appropriate marker to investigate the Asian Uralic male contribution to the Hungarian gene pool.

\section{Paleolithic and neolithic genetic components in Hungary}

The two Y-specific markers, the $49 \mathrm{a}, \mathrm{f} \mathrm{Ht} 15$ and the $12 \mathrm{f} 2-8 \mathrm{~Kb}$ allele which, as previously said, are considered European preneolithic and neolithic lineages of the modern European genetic structure, are both infrequent in Hungarians, as well as in Czechoslovaks. ${ }^{36}$ It seems therefore, that the migrations which spread the neolithic from south-eastern to north- 
western Europe affected eastern Europe only marginally, although the frequency ( $12 \%$, Table 1$)$ of the neolithic mtDNA haplogroup $\mathrm{J},{ }^{19}$ is within the range of the European values. On the other hand, the low frequency of 49a,f Ht 15 indicates that also the most important pre-neolithic component of the north-western and western European populations, where it attains its maximum values $(50-70 \%)^{22,37,38}$ and probably rose, ${ }^{49}$ is scarcely represented in eastern Europe.

The most frequent Hungarian compound haplotypes (Table5) include the 49a,f $\mathrm{Ht} 11$. This haplotype is rather uncommon in western Europe $\mathrm{B}^{35,37,38}$ and has a frequency of $21.0 \%$ in a sample from former Czechoslovakia, ${ }^{36}$ and $42.5 \%$ from Hungary (Table2). Also illustrated in the network (Figure 3), the Hungarian 49a,f Ht 11 chromosomes (c-Hts3, 10-12) are almost exclusively $\mathrm{YAP}^{-}$, as well as in other Europeans (G Passarino 2000, personal communication), and further characterised by the YCAll a5-b1haplotype (c-Hts 10-12 in Table5). The remarkable incidence of these c-hapl otypes, particularly of the c-Ht 12, suggests that Hungarian population underwent expansion. Since the small size of the sample and the uncertainty of the mutation rate ${ }^{50}$ do not allow this expansion to be reliably dated, the results we obtained are compatible with two not necessarily alternative hypotheses. One is of an ancient presence of $\mathrm{YAP}^{-} / 49 \mathrm{a}$, $\mathrm{f} \mathrm{Ht} 11$ in eastern European populations which, during the last glaciation, retreated into southern Ukraine $\mathrm{U}^{51}$ and subsequently expanded at the end of the glaciation when people returned to the abandoned territories. In this case, the YAP ${ }^{-}$/ $49 a, f \mathrm{Ht} 11$ would represent the eastern European counterpart of the western European preneolithic 49a,f Ht 15. The second, a more recent arrival in Hungary of this haplotype due to the spread of the Yamnaia culture from southern Ukraine, today recognised as a second development of the farming economy due mainly to the domestication of horses. $^{52}$ It characterised nomad peoples who migrated at different times, from $4300 \mathrm{BC}$ to $3000 \mathrm{BC}^{53}$ or more recently. ${ }^{54}$ According to Gimbutas ${ }^{55}$ and Piazza, ${ }^{56}$ they brought the Indo-European languages to Europe and to India. ${ }^{54,57}$ Interesting in this regard is that, out of Europe, the YAP $/ 49 a, f$ $\mathrm{Ht} 11$ associated with YCAll a5-b1 is frequent in the north of India (G Passarino 2000, personal communication). It would clearly be interesting to verify these hypotheses against further data on eastern European and Asian populations.

\section{Acknowledgements}

We are grateful to $\mathrm{H}-\mathrm{J}$ Bandelt who provided us with the network program. Research was partially supported by Ministry of University (PRIN ex MURST 40\%) and by CNR PF Beni cultrali (Grant NoCNR9700588PF36) awarded to ASSB. The support of 'Impresa Cundari, Cosenza' is also acknowledged. AL was a UNIDO Fellow and L Q-M is a Marie Curie Fellow of the EC (ERBFM BICT-961830).

\section{References}

1 Cavalli-Sforza LL, Piazza A, Menozzi P, Mountain J: Reconstruction of human evolution: bringing together genetic, archaeological and linguistic data. Proc Natl Acad Sci USA 1988; 85: 6002-6006.

2 Sokal RR: Genetic, geographic and linguistic distances in Europe. Proc Natl Acad Sci USA 1988; 85: 1722-1726.

3 Czeizel A, Benkmann H-G, Goedde HW (eds): Genetics of the Hungarian Population. Springer Verlag, Berlin, 1991.

4 Guglielmino CR, Piazza A, Menozzi P, Cavalli-Sforza LL: Uralic genes in Europe. Am J Phys Anthrop 1990; 83: 57-68.

5 Vilkki J, Savontaus ML, Nikoskelainen EK: Human mitochondrial DNA types in Finland. Hum Genet 1988; 80: 317-321.

6 Lahermo P, Sajantila A, Sistonen P et al: The genetic relationship between the Finns and Finnish Saami (Lapps): analysis of nuclear DNA and mtDNA. Am J Hum Genet 1996; 58: 1309-1322.

7 Torroni A, Huoponen K, Francalacci P et al: Classification of European mtDNAs from an analysis of three European populations. Genetics 1996; 144: 1835-1850.

8 Torroni A, Bandelt H-J, D'Urbano L et al: mtDNA analysis reveals a major late paleolithic population expansion from southwestern to northeastern Europe. Am J Hum Genet 1998; 62: 1137-1152.

9 Jobling MA, Samara V, Pandya A et al : Recurrent duplication and deletion polymorphisms on the long arm of the $Y$ chromosome in normal males. Hum Mol Genet 1996; 5: 1767-1775.

10 Zerjal T, Dashnyam B, Pandya A et al: Genetic relationships of Asians and Northern Europeans, revealed by Y-chromosomal DNA analysis. Am J Hum Genet 1997; 60: 1174-1183.

11 Kittles RA, Perola M, Peltonen $L$ et al: Dual origins of Finns revealed by $Y$ chromosome haplotype variation. Am J Hum Genet 1998; 67: 1171-1179.

12 Poloni ES, Semino O, Passarino G et al: Human genetic affinities for $Y$ chromosome P49a,f/Taql haplotypes show strong correspondence with linguistics. Am J Hum Genet 1997; 61: 1015-1035.

13 Passarino G, Semino O, Quintana-Murci L, Excoffier L, Hammer $M$, Santachiara-Benerecetti AS: Different genetic components in the Ethiopian population, identified by mtDNA and Y-chromosome polymorphisms. Am J Hum Genet 1998; 62: 420-434.

14 Quintana-Murci L, Semino O, Poloni ES et al: Y-chromosome specific YCAII, DYS19 and YAP polymorphisms in human populations: a comparative study. Ann Hum Genet 1999; 63: 153-166.

15 Lahermo $\mathrm{P}$, Savontaus $\mathrm{M}-\mathrm{L}$, Sistonen $\mathrm{P}$ et al: $\mathrm{Y}$ chromosomal polymorphisms reveal founding lineages in the Finns and the Saami. Eur J Hum Genet 1999; 7: 447-458.

16 Brega A, Gardella R, Semino O et al: Genetic studies on the Tharu population of Nepal: restriction endonuclease polymorphisms of mitochondrial DNA. Am J Hum Genet 1986; 39: 502-512.

17 Ballinger SW, Schurr TG, Torroni A et al: Southeast Asian mitochondrial DNA analysis reveals genetic continuity of ancient Mongoloid migrations. Genetics 1992; 130: 139-152.

18 Lamminen T, Huoponen K, Sistonen P et al: MtDNA haplotype analysis in Finnish families with Leber hereditary optic neuroretinopathy. Eur J Hum Genet 1997; 5: 271-279.

19 Macaulay V, Richards M, Hickey E et al: The emerging tree of West Eurasian mtDNAs: A synthesis of control-region sequences and RFLPs. Am J Hum Genet 1999; 64: 232-249.

20 Ngo KY, Vergnaud G, Johnson C, Lucotte G, Weissenbach J: A DNA probe detecting multiple haplotypes of human $Y$ chromosome. Am J Hum Genet 1986; 38: 407-418.

21 Casanova $M$, Leroy $P$, Boucekkine $C$ et al: A human Y-linked DNA polymorphism and its potential for estimating genetic and evolutionary distance. Science 1985; 230: 1403-1406.

22 Semino O, Passarino G, Brega A, Fellous M, Santachiara-Benerecetti AS: A view of the Neolithic demic diffusion in Europe through two $Y$ chromosome-specific markers. Am J Hum Genet 1996; 59: 964-968.

23 Hammer MF, Horai S: Y chromosomal DNA variation and the peopling of Japan. Am J Hum Genet 1995; 56: 951-962. 
24 Roewer L, Arnemann J, Spurr NK, Grzeschik KH, Epplen JT: Simple repeat sequences on the human Y-chromosome are equally polymorphic as their autosomal counterpart. Hum Genet 1992; 89: 389-394.

25 Mathias $N$, Bayes $M$, Tyler-Smith C: Highly informative compound haplotypes for the human $\mathrm{Y}$ chromosome. Hum Mol Genet 1994; 3: 115-123.

26 Passarino G, Semino O, Bernini LF, Santachiara-Benerecetti AS: Pre-Caucasoid and Caucasoid genetic features of the Indian population, revealed by mtDNA polymorphisms. Am J Hum Genet 1996; 59: 927-934.

27 Torroni A, Sukernik RI, Schurr TG et al: MtDNA variation of aboriginal Siberians reveals distinct genetic affinities with Native Americans. Am J Hum Genet 1993; 53: 591-608.

28 Bandelt H-J, Forster P, Sykes BC, Richards MB: Mitochondrial portraits of human populations using median networks. Genetics 1995; 14: 743-753.

29 Röhl A, Mihn DL: Network: a program package for calculating phylogenetic networks. Mathemathisches Seminar, University of Hamburg, 1997.

30 OthaT, Kimura M: The model of mutation appropriate to estimate the number of electrophoretically detectable alleles in genetic population. Genet Res 1973; 22: 201-204.

31 Spurdle $A B$, Hammer MF, Jenkins T: The $Y$ Alu polymorphism in southern African populations and its relationship to other Y-specific polymorphisms. Am J Hum Genet 1994; 54: 319-330.

32 Johnson MJ, Wallace DC, Ferris SD, Rattazzi MC, Cavalli-Sforza LL: Radiation of human mitochondrial DNA types analyzed by restriction endonuclease cleavage patterns. J Mol Evol 1983; 19: 255-271.

33 Torroni A, Miller JA, Moore LG et al: Mitochondrial DNA analysis in Tibet: implications for the origin of the Tibetan population and its adaptation to high altitude. Am J Phys Anthrop 1994; 93: 189-199.

34 Torroni A, Semino O, Scozzari $R$ et al: $Y$ Chromosome DNA polymorphisms in human populations: differences between Caucasoids and Africans detected by 49 a, f probes. Ann Hum Genet 1990; 54: 287-296.

35 Persichetti F, Blasi $P$, Hammer $M$ et al: Disequilibrium of multiple DNA markers on the human $Y$ chromosome. Ann Hum Genet 1992; 56: 303-310.

36 Santachiara-Benerecetti AS, Semino O, Passarino G et al: The common, Near-Eastern origin of Ashkenazi and Sephardi Jews supported by Y-chromosome similarity. Ann Hum Genet 1993; 57: 55-64.

37 Jobling MA: A survey of long-range DNA polymorphisms on the human $Y$ chromosome. Hum Mol Genet 1994; 3: 107-114.

38 Lucotte G, Hazout S: Y-chromosome DNA haplotypes in Basques. J Mol Evol 1994; 42: 472-475.

39 de Kniff P, Kayser M, Caglià A et al: ChromosomeY microsatellites: population genetic and evolutionary aspects. Int J Legal M ed 1997; 110: 134-140.

40 Roewer L, Kayser M, Dieltjes P et al: Analysis of molecular variance (AMOVA) of Y-chromosome-specific microsatellites in two closely related human populations. Hum Mol Genet 1996; 5: 1029-1033.

41 Kayser M, Caglià A, Corach D et al: Evaluation of chromosomal STRs: a multicenter study. Int J Legal Med 1997; 110: 125-133.

42 Muller S, Gomolka M, Walter H: The Y-specific SSLP of the locus DYS19 in four different European samples. Hum Hered 1994; 44: 298-300.
43 Gomolka M, Hundrieses J, Nurnberg P, Roewer L, Epplen JT, Epplen C: Selected di- and tetranucleotide microsatellites from chromosomes 7, 12, 14, and $Y$ in various Eurasian populations. Hum Genet 1994; 93: 592-596.

44 Ciminelli BM, Pompei F, Malaspina $P$ et al: Recurrent simple tandem repeat mutations during human Y-chromosome radiation in Caucasian subpopulations. J Mol Evol 1995; 41: 966-973.

45 Santachiara-Benerecetti AS, Semino O: Y-chromosome polymorphisms and history of populations. Cell Pharmacol 1996; 3: 199-204.

46 Malaspina P, Cruciani F, Ciminelli BM et al: Network analyses of Y-chromosomal types in Europe, northern Africa, and western Asia reveal specific patterns of geographic distribution. Am J Hum Genet 1998; 63: 847-860.

47 Passarino G, Semino O, Modiano G, Santachiara-Benerecetti AS: COII/tRNA ${ }^{\text {Lys }}$ intergenic 9bp deletion and other mtDNA markers clearly reveal that the Tharus (Southern Nepal) have oriental affinities. Am J Hum Genet 1993; 53: 609-618.

48 Soodyall $H$, Vigilant $L$, Hill AV, Stoneking $M$, Jenkins T: mtDNA control region sequence variation suggests multiple independent origins of an 'Asian-specific' 9-bp deletion in sub-Saharan Africans. Am J Hum Genet 1996; 58: 595-608.

49 Quintana-Murci L, Semino O, Minch E, Brega A, SantachiaraBenerecetti AS: Further characteristics of proto-European Y-chromosomes. Eur J Hum Genet 1999; 7: 603-608.

50 Brinkmann B, Klintschar M, Neuhuber F, Huhne J, Rolf B: Mutation rate in human microsatellites: influence of the structure and length of the tandem repeat. Am J Hum Genet 1998; 62: 1408-1415.

51 Otte M: The North-Western European plain around 18000 Bc. In: Soffer O, Gamble C (eds). The World at 18000 B.P. Unwin Hyman: London, 1990, vol 1, pp 54-68.

52 Cavalli-Sforza LL, Menozzi P, Piazza A: The History and Geography of Human Genes. Princeton University Press: Princeton, NJ, 1994.

53 Gimbutas M: Proto-Indo-European culture: The Kurgan culture during the fifth, fourth and third millennia BC. In: Cardona G, Hoenigswald HM, Senn AM (eds). Indo-European and Indo-Europeans. University of Pensiylvania Press: Philadelphia, 1970.

54 Renfrew C: Archaeology and Ianguage; the puzzle of IndoEuropean origin. Jonathan Cape: London, 1987.

55 Gimbutas M: The civilization of the goddess: The world of Old Europe. Harper: San Francisco, 1991.

56 Piazza A: Who are Europeans? Science 1993; 260: 1767-1769.

57 Zvelebil M: The rise of the nomads in Central Asia. In: A Sherrat (eds). The Cambridge Encyclopedia of Archeology. Crown: New York, 1980.

58 Torroni A, Petrozzi M, D'Urbano L et al: Haplotype and phyloge netic analyses suggest that one European-specific mtDNA background plays a role in the expression of Leber hereditary optic neuropathy by increasing the penetrance of the primary mutations 11778 and 14484. Am J Hum Genet 1997; 60: 1107-1121.

59 Hammer MF: A recent insertion of an Alu element on the $Y$ chromosome is a useful marker for human population studies. Mol Biol Evol 1994; 11: 749-761.

60 Brega A, Torroni A, Semino $O$ et al: The p12f2/Taql Y-specific polymorphism in three groups of Italians and in a sample of Senegalese. Gene Geog 1987; 1: 201-206. 